a dozen fine specimens of Funiculina, the largest of which measured nearly four feet in length. The bed must be of considerable extent, as the hauls were not on the same spot, and both brought up equally good specimens of these magnificent pennatulids. Most of the large specimens of Funiculina, by the way, were not caught in the trawl-net, but were balanced across the front of the frame, at each end, in such a precarious position as to make one wonder how many others had been lost in hauling in. The bottom deposit was evidently fine mud. W. A. Herdman.

S.Y. Runa,

Sound of Iona, July II.

\section{On the Non-simultaneity of Suddenly Beginning} Magnetic Storms.

IN his paper "On the Supposed Propagation of 'Equatorial 'Magnetic Disturbances with Velocities of the Order of a Hundred Miles per Second," read before the Physical Society of London, November i I, I9ro, and published in the Proceedings of that society, vol. xxiii, pp. $49-57$, Dr. Chree, in reviewing my paper published in the Journal of Terrestrial Magnetism (vol. 15, pp. 93-105), expressed some doubts as to my views on the subject of the non-simultaneity of suddenly beginning magnetic storms.

It seems to me that there should not be any doubt as to my position on this point when I stated in my abovementioned paper (loc. cit. p. I03) that the evidence there presented confirmed what Dr. Bauer had stated, namely, that magnetic storms do not begin at the same instant all over the world, and added a little further on that a new view-point in the discussion and analysis of magnetic storms is thus introduced, meaning that a new view-point must now be had on account of this non-simultaneity of the occurrence of the beginning of the storms which, I believe, the data shows to exist.

I agree with Dr. Bauer in his conclusion that the abruptly beginning magnetic storms are not simultaneous all over the world, and this conclusion, it seems to me, is supported, not only by the data in my paper, but by that in his paper which appeared prior, and in that which has appeared subsequent, to mine.

U.S. Coast and Geodetic Survey, Washington, D. C.

\section{The Number of Possible Elements and Mendeléeff's "Cubic" Periodic System.}

AcCoRDing to Rutherford's theory of " single scattering" ("On the Scattering of $\alpha$ and $\beta$ Particles by Matter and the Structure of the Atom," Phil. Mag., May, Iori), and to Barkla's " Note on the Energy of Scattered X-Radiation" (ibid.), the numbers of electrons per atom is half the atomic weight; thus, for $U$, about i2a. Now, a reconstruction of Mendeléeff's " cubic" periodic sy:stem, as suggested in his famous paper "Die Beziehungen zwischen den Eigenschaften der Elemente und ihren Atomgewichten" (Ostw. Klass., No. 68, pp. 32, 36, 37, and 74), gives a constant mean difference between consecutive atomic weights $=2$, and thus, from $\mathrm{H}$ to $\mathrm{U}, 120$ as the number of possible elements (van den Broek, "Das Mendelejeff'sche 'Kubische' Periodische System der Elemente und die Einordnung der Radioelemente in dieses System," Physik. Zeitschr. 12, p. 490). Hence, if this cubic periodic system should prove to be correct, then the number of possible elements is equal to the number of possible permanent charges of each sign per atom, or to each possible permanent charge (of both signs) per atom belongs a possible element.

Noordwijk-Zee, June 23 .

A. VAN DEN BROEK.

\section{Phases of Evolution and Heredity.}

I sHould like your reviewer of the above book in NATURE for May 25 to consider the following points :-

I. In a tall-dwarf crossing where the results are read in plants, the ultimate ratios considered as due to a probability combination of the egg-cells and pollen grains the influence of which necessarily ends within a generation, explain why we do not get the ratio in the plants coming out in $\mathrm{F}^{\mathbf{1}}$.

2. To mv query, "How is the recessive element expressed in $F^{1}$ ? It has not disappeared as it reappears in NO. 2 I77, VOL. 87$]$
$\mathrm{F}^{2}$ unaltered. It is not expressed in the 'soma' of the plant: where is it?" your reviewer answers "In the germ-cells."

If, however, the determinants of the recessives are ex pressed in the germ-cells, i.e., in the propagative part of the plant, so must those for the impure dominant and dominant plants. These plants segregate in a $\mathbf{1}: \mathbf{2}: \mathbf{1}$ ratio, and therefore the determinants for the contrasted unit-characters must be in that ratio in the propagative part of the oospores. Does the reviewer not admit the accuracy of my view after all?

5 Randolph Cliff, Edinburgh.

I FIND it very difficult to follow Dr. Berry Hart. If he means, by the question which concludes his letter, to ask whether I accept his theory as truly representing, once and for all, the causes which determine the Mendelian ratio $1: 2: 1$, my answer is an unqualified negative; not because I think I know what the true theory is, but because I do not think the time is yet ripe to formulate it. Dr. Hart's theory is evidently different from the accepted Mendelian theory; and it may be nearer the truth. Whether it is or not, further experiment alone can show.

THE REVHeWER.

\section{Available Laboratory Attendants.}

THE London County Council has for some time been referring to us a certain number of boys who have been trained as laboratory attendants in their higher grade and secondary schools, and whose services they are unable to retain after they have attained seventeen years of age. We are anxious to find suitable vacancies either in chemical works or laboratories for these boys, who are of a distinctly superior type and some of whom have profited by their experience to pass the Board of Education examinations in inorganic chemistry.

Some of these boys who were placed by us, thanks to a letter published by you last year, are doing well and giving satisfaction to their respective employers.

Should any of your readers, now or at any future time, have a vacancy for such a lad, I should be glad to hear from him.

G. E. Reiss, Hon. Sec.

Apprenticeship and Skilled Employment Association,

36 Denison House, 296, Vauxhall Bridge Road,

London, S.W. July 6 .

\section{Mersenne's Numbers.}

I DESIRE to announce the discovery which I have made that $\left(2^{181}-1\right)$ is divisible by 43441 . This leaves only 16 of the numbers $\left(2_{q}-1\right)$ originally reported composite by Mersenne, still unverified. I have submitted my determination to Lt.-Col. Allan Cunningham, R.E., who has kindly verified it.

It is interesting to know that while $\left(2^{181}-1\right)$ is divisible by $4344 \mathrm{I}$, the quotient when divided by this number (4344I) leaves a remainder 21839 . This latter result has been verified by two divisions.

Market Place, Stockport, June 12 .

HERBERT J. Woodall.

\section{The Fox and the Fleas.}

SOME readers of NATURE may be interested in seeing the following passage from one of Liebig's letters to Wöhler, dated Giessen, June 24,1849 , as showing that the story has long been familiar, at least in Germany :-

" Das freiheitsmörderische Gesindel ist nun, wie beim Fuchs die Flöhe in dem Bündel Heu, in einer Schlinge gefangen ...." \&c. William A. Tilden.

The Oaks, Northwood, Middlesex, July io.

\section{Cabbage White Butterfly.}

Would some entomologist state if he knows of any reference to the fact that the larvæ of the Large Cabbage White seek to arrange themselves in pairs-male and female-when they pupate?

Can the sexes be distinguished externally in the larval and in the pupal stages?

E. W. REAN.

Sutherland Technical School, Golspie. 